\title{
UPAYA PEMBINAAN TARI ANAK DI SANGGAR TARI PUTRA BIMA RESPATI SURABAYA
}

\author{
Pance Mariati \\ Universitas Nahdlatul Ulama Surabaya \\ e-mail: pance_mariati@unusa.ac.id
}

\begin{abstract}
Abstrak: Upaya membentengi budaya daerah agar tidak mudah terpengaruh oleh budaya asing adalah dengan cara menguatkan serta melestarikan kesenian daerah. Upaya yang dilakukan untuk melestarikan kesenian daerah kota Surabaya khususnya untuk anak-anak adalah pembelajaran tari yang dilakukan di sanggar tari. Tujuan dilaksanakannya kegiatan tersebut adalah memberikan ruang bagi anak-anak untuk berekspresi dan berkarya seni, agar sejak dini anak dapat mengenal dan mencintai kesenian. Berdasarkan pemaparan di atas, tujuan dari penelitian ini adalah, 1) untuk mengetahui latar belakang pembelajaran tari anak di Sanggar Tari Putra Bima Respati Surabaya; 2) untuk mendeskripsikan upaya pembinaan tari anak yang dilakukan di Sanggar Putra Bima Respati. Metode yang digunakan dalam penelitian ini adalah pendekatan kualitatif yang mendeskripsikan upaya pembinaan tari anak di Sanggar Putra Bima Respati Surabaya. Hasil dari penelitian ini menunjukkan bahwa proses pembelajaran tari yang dilakukan di Sanggar Tari Putra Bima Respati sanggat disiplin dan tegas sehingga menghasilkan penari-penari yang mempunyai teknik gerak dan tubuh yang bagus dalam menari. Oleh karena itu, prestasi yang diperoleh sanggar Putra Bimarespati sampai pada tingkat Provinsi, Nasional, sampai Internasional.
\end{abstract}

Kata Kunci: pembinaan, tari anak, Sanggar Tari Putra Bima Respati

\begin{abstract}
The effort to fortify the regional culture so as not to be easily influenced by foreign culture is by strengthening and preserving local arts. Efforts made to preserve the arts of the city of Surabaya, especially for children is a dance learning conducted in the dance studio. The purpose of the implementation of these activities is to provide space for children to express and work art, so that early on children can recognize and love the arts. Based on the above explanation, the purpose of this research is, (1) to know the background of children dance learning in Sanggar Dance Putra Bima Respati Surabaya; (2) to describe the effort of children dance development conducted in Sanggar Putra Bima Respati. The method used in this study is a qualitative approach that describes the effort of coaching a child in the studio Putra Bima Respati Surabaya. The results of this study indicate that the process of dance learning conducted in Sanggar Dance Putra Bima Respati sangat discipline and resolute to produce dancers who have good motion and body techniques in dancing. Therefore, the achievements obtained by Putra Bimarespati studio up to Provincial level, National to International level.
\end{abstract}

Keyword: coaching, children dance, Dance Studio Putra Bima Respati

\section{PENDAHULUAN}

Tradisi kesenian merupakan bagian dari seni tradisi yang melekat dengan kehidupan budaya tradisi masyarakat kita. Jadi, seni tradisi sangat penting untuk diteladani sebagai salah satu filter dari pengaruh budaya asing yang negatif. Sekaligus sebagai sumber kreativitas dalam menyikapi perkembangan seni tradisi ke depan.

Pembinaan kesenian dapat dilakukan melalui masing-masing individu dalam rangka menguatkan seni tradisi. Keinginan untuk terus melestarikan kesenian yang telah hidup dan berkembang di wilayah yang telah menjadi bagian dari kita, 
merupakan kewajiban yang menjadi tanggung jawab pokok bagi seluruh lapisan masyarakat. Pembinaan Kesenian Tradisional yang mentradisi sesuai dengan konteks zamannya, tidak berarti harus memodernkan karya tradisional secara total. Konsep dan bentuk karya harus tetap ada, namun pengemasannya disesuaikan dengan kebutuhan masa kini sesuai dengan akselerasi dan mobilitas kehidupan budaya manusia (Jariyanto, 2007).

Pembinaan secara berkesinambungan melalui sekelompok lembaga dapat dilaksanakan oleh daerah-daerah yang memahami pentingnya nilainilai budaya bagi perkembangan kesenian daerah tersebut. Di era globalisasi seperti sekarang, budaya daerah semakin terkikis oleh budaya global yang memang memiliki nilai-nilai yang berbeda dengan budaya lokal. Memudarnya eksistensi kesenian daerah merupakan salah satu bukti kurangnya perhatian dan pemberdayaan dari pihak terkait sehingga kebudayaan daerah semakin terpuruk keberadaannya. Oleh karena itu, pembinaan kesenian daerah sangat penting untuk dilaksanakan.

Seperti halnya pembinaan kesenian yang dilakukan di Surabaya bertujuan untuk melestarikan kesenian-kesenian daerah yang ada. Mengajak masyarakat Surabaya untuk dapat mengenal dan mengembangkan kesenian agar atmosfer kesenian yang ada di Surabaya menjadi lebih hidup. Masyarakat Surabaya yang memiliki gaya hidup metropolis masih tetap peduli dengan kesenian, baik kesenian tradisi maupun modern.

Salah satu upaya pembinaan kesenian yang ada di Surabaya khususnya tari anak dilakukan di Sanggar Tari Putra Bima Respati. Sanggar Tari Putra Bima Respati merupakan salah satu sanggar di Surabaya yang mengajarkan tari tradisi mulai dari anak-anak sampai remaja. Pembelajaran tari yang diterapkan di sanggar tersebut mampu mencetak penari-penari yang terampil dan bagus. Tujuan yang ingin dicapai dalam penelitian ini adalah untuk mengetahui latar belakang pembelajaran tari anak di Sanggar Tari Putra Bima Respati Surabaya serta mendeskripsikan upaya pembinaan tari anak yang dilakukan di Sanggar Putra Bima Respati.

\section{KAJIAN TEORI}

\section{Definisi Pembinaan}

Pembinaan dan pengembangan kesenian sebagai ungkapan budaya bangsa diusahakan agar mampu menampung dan menumbuhkan daya cipta para seniman, memperkuat jati diri bangsa, meningkatkan apresiatif dan kreativitas masyarakat, memperluas kesempatan masyarakat untuk menikmati dan mengembangkan seni budaya bangsa serta memberikan inspirasi pembangunan (Sesuai dengan ketetapan MPR No. 11 tahun 1999).

Wilayah Pendidikan Kesenian Masyarakat sering dipersepsikan sebagai bentuk pembinaan kesenian. Pembinaan kesenian dapat dikelompokkan menjadi tiga. (a) Pembinaan seni oleh Pemerintah, (b) pembinaan seni oleh pihak swasta dan LSM seni budaya, (c) Pembinaan seni oleh seniman atau masyarakat sendiri (Jarianto, 2007: 6).

Jadi yang dimaksud dengan pembinaan kesenian adalah upaya untuk melestarikan kesenian khususnya seni tari agar dapat berkembang dan berdaya guna. Pembinaan dapat dilakukan oleh Seniman, Pemerintah dan Lembaga Swadaya Masyarakat seni budaya.

Menurut Jarianto (2007:8), dalam usaha memajukan kesenian, Dinas P dan K Provinsi Jawa Timur menentukan pola pembinaan kesenian sekolah melalui jaringan kerjasama dengan seluruh jaringan institusi. Program pembinaan 
kesenian dirancang melalui prosedur yang mapan. Dalam konteks pendidikan diselenggarakan berbagai forum pelatihan, lokakarya, seminar, dan dialog seni. Evaluasi program dilakukan melalui berbagai kegiatan yang bersifat kompetisi dan apresiatif yang dilakukan secara periodik.

Pembinaan yang dimaksud dalam penulisan ini adalah upaya seniman dalam memberdayakan kesenian khususnya seni tari untuk siswa agar atmosfer kesenian yang ada di Surabaya tetap tumbuh dan berkembang dan juga menemukan bibit penari-penari yang mempunyai kualitas bermutu.

\section{Seni Tari}

\section{a. Seni}

Karya seni adalah bentuk ekspresi yang diciptakan bagi persepsi kita lewat indra dan pencitraan, yang diekspresikan adalah perasaan manusia. Pengertian perasaan di sini dalam lingkup yang luas, yakni sesuatu yang dapat dirasakan, sensasi fisik, penderitaan dan kegembiraan, gairah dan ketenangan, tekanan pikiran, emosi yang kompleks yang berkaitan dengan kehidupan manusia. Menurut Soedarsono dalam Pekerti (2007:1.7) seni berasal dari kata sani dalam bahasa Sansekerta yang berarti pemujaan, pelayanan, donasi, permintaan atau pencaharian dengan hormat dan jujur. Dalam perkembangan selanjutnya muncul berbagai pengertian seni, yaitu:

1) Seni adalah kemampuan membuat sesuatu dalam hubungannya dengan upaya mencapai suatu tujuan yang ditentukan oleh rasio atau logika atau gagasan tertentu (Aristoteles dalam Pekerti, 2007:1.7).

2) Seni merupakan kegiatan sadar manusia dengan perantaraan tanda-tanda lahiriah tertentu untuk menyampaikan perasaan-perasaan yang telah dihayatinya kepada orang lainnya, sehingga mereka kejangkitan perasaan yang sama dan juga mengalaminya (Tolstoy dalam Pekerti, 2007:1.7).

3) Seni dalam arti sempit adalah kegiatan olah bentuk (dalam arti material), olah teknik penyajian dan olah pengalaman, pengkajian ulang, eksplorasi kemungkinan baru dalam memandang, merasakan, menghayati sesuatu dan upaya-upaya mendiagnosis kondisi zaman dan sebagainya (Sugiarto dalam Pekerti, 2007: 1.7).

4) Seni merupakan hasil kreasi akal budi dan rasa manusia yang hidup sepanjang masa dan dikagumi oleh manusia yang tidak terbatas pada ruang dan waktu (Parmono, 2008:63).

Berdasarkan definisi-definisi tentang seni di atas dapat diartikan bahwa seni adalah segala sesuatu yang memiliki nilai estetis yang lahir dari kreativitas manusia yang digunakan untuk menyampaikan perasaan-perasaan yang telah dihayatinya kepada orang lainnya, sehingga mereka kejangkitan perasaan yang sama dan juga mengalaminya.

\section{b. Tari}

Tari menurut Edi Sedyawati dalam Hidayat (2005:2), seorang arkeolog yang menaruh minat besar pada seni tari memahami seni tari sebagai berikut:

1) Pengertian tari bersifat terbatas adalah susunan gerak beraturan yang dengan sengaja dirancang untuk mencapai suatu kesan tertentu.

2) Pengertian tari bersifat umum adalah bentuk upaya untuk mewujudkan keindahan susunan gerak dan irama yang dibentuk dalam satuansatuan komposisi.

Tari menurut Wisnoe Wardhana dalam Hidayat (2005:3), salah seorang tokoh tari mo- 
dern Indonesia, mendefinisikan Tari sebagai kerja rasa dari manusia yang penyalurannya melewati urat-urat. Pemahaman tentang gerak dan di dalamnya secara implisit terdiri dari otot dan atau urat tubuh, maka pengertian tari terkait dengan gerak dan sistem mekanisasi tubuh (uraturat) yang bersifat teknis.

Tari menurut BPA Soerjodiningrat dalam Hidayat (2005:3) seorang tokoh tari gaya Yogyakarta dalam bukunya yang berjudul Babad lan Mekaring djoged Djawi,sebagai berikut.

Ingkang dipun wastani djoged inggih punika ebahing sadaja saranduning badan, kasarengan ungeling gangsa (gamelan), katata pikatuk wiramaning gending, djumbuhing pasemon kalajang pikadjenging djoged (BPA. Surjadiningrat, 1934:3).

Tari yaitu bergeraknya seluruh anggota badan, diiringi bunyi gamelan (instrumen gamelan), ditata berdasarkan irama lagu pengiring (gending), menyatukan simbolisasi dengan maksud sebuah tarian.

Berdasarkan definisi-definisi tari di atas dapat disimpulkan bahwa tari adalah gerak tubuh yang indah dengan diiringi oleh musik dan mempunyai makna yang ingin disampaikan oleh seorang koreografer.

Seni tari dalam penulisan ini adalah kategori lomba untuk siswa dalam pentas seni pelajar yang dilaksanakan di Taman Remaja Surabaya. Adapun macam-macam tari yang dilombakan meliputi Tari Tradisional, Tari Kreasi, Tari Modern dan Tari Ngremo.

\section{METODE PENELITIAN}

Penelitian ini membahas tentang upaya pembinaan tari anak di sanggar tari Putra Bima Respati Surabaya. Metode penelitian yang digunakan adalah metode deskriptif analisis kualitatif. Pada penelitian ini terdapat permasalahan tentang latar belakang pembelajaran tari anak di Sanggar
Tari Putra Bima Respati Surabaya serta upaya pembinaan tari anak yang dilakukan di Sanggar Putra Bima Respati yang harus dipecahkan. Permasalahan tersebut membutuhkan data, baik data tentang objek yang akan diteliti maupun data untuk menggarap. Data yang dibutuhkan sebagai objek yang akan digarap adalah upaya pembinaan tari anak di sanggar tari Putra Bima Respati, sedangkan data untuk menggarap berkaitan dengan teori dan konsep.

\section{HASIL DAN PEMBAHASAN}

\section{Latar Belakang Pembinaan Tari}

Sanggar merupakan tempat untuk kegiatan seni baik lukis, tari, musik dan juga kecantikan. Sanggar juga merupakan salah satu tempat berkumpulnya orang-orang yang ingin berlatih terkait dengan hal-hal kesenian, seperti halnya sanggar tari. Sanggar tari sudah banyak sekali didirikan di Surabaya seperti Sanggar Raff Dance, Sanggar Tydif, Sanggar Spectra Dance Studio, Sanggar Tari Putra Bima Respati dan lain-lain. Sanggar-sanggar tersebut mampu mencetak penari-penari dengan kemampuan yang sangat bagus dan menambah daftar seniman tari di Jawa Timur. Masing-masing sanggar tersebut juga memiliki pola pengajaran yang unik dan berbeda-beda dalam membentuk para penarinya. Salah satunya yakni Sanggar Tari Putra Bimarespati Surabaya. Sanggar Putra Bimarespati didirikan pada tahun 1992 di Tambak Segaran Wetan. Nama sanggar tersebut terdiri dari dua nama yaitu Putra Bima yang berarti Gathutkaca dan Pati yang berarti hari lahir. Sanggar ini didirikan oleh bapak Saryono, S.Sn. Sanggar Putra Bimarespati ini terdapat didua tempat yaitu di Tambak Segaran Wetan dan Balai Pemuda.

Pemilik sanggar tersebut bernama Bapak Saryono, S.Sn. Beliau lahir di Banyuwangi tepat- 
nya pada tanggal 21 Februari 1965. Bapak Saryono bertempat tinggal di Tambak Segaran Wetan, Kelurahan Rangkah, Kecamatan Tambaksari yang juga merupakan lokasi sanggar Putra Bimarespati. Pendidikan terakhir Pak Saryono adalah S1 Institut Seni Indonesia (ISI) Solo lulus pada tahun 1990. Secara kualitas kepenarian sudah tidak diragukan lagi karena memang beliau sudah lama berkecimpung dalam dunia kesenian. Baik menjadi penari maupun penata tari yang terkenal. Hal ini dapat dilihat dari prestasi-prestasi yang telah dicapainya. Adapun pengalaman berkesenian Saryono yakni menjadi seniman di Jakarta selama satu tahun, kemudian pulang ke Surabaya dan mendirikan sanggar yang diberi nama Sanggar Tari Putra Bimarespati. Selain itu, ia juga menjadi pelatih tari di Taman Budaya Surabaya.

Latar belakang yang mendasari pembinaan tari anak di Sanggar Tari Putra Bimarespati adalah keinginan Saryono supaya generasi muda khususnya anak-anak di Surabaya tidak melupakan tari tradisional khas Surabaya salah satunya yakni Tari Remo. Selain itu, dengan berlatih menari, dapat membentuk rasa tanggung jawab pada diri sendiri dan juga orang lain. Melatih kedisiplinan dan juga memberikan pelajaran yang tidak pernah dipelajari pada dunia anak. Dengan belajar menari, anak akan mampu mengoordinasikan gerakan tubuhnya. Melatih motorik halus dan motorik kasar anak, sehingga anak mempunyai kepekaan emosi terhadap sesama. Memberikan kegiatan positif anak agar dapat mengurangi aktivitasnya yang mayoritas saat ini didominasi dengan bermain gadget.

\section{Upaya Pembinaan Tari Anak}

Pembinaan dan pengembangan kesenian sebagai ungkapan budaya bangsa diusahakan agar mampu menampung dan menumbuhkan daya cipta para seniman, memperkuat jati diri bangsa, meningkatkan apresiatif dan kreativitas masyarakat, memperluas kesempatan masyarakat untuk menikmati dan mengembangkan seni budaya bangsa serta memberikan inspirasi pembangunan (Sesuai dengan ketetapan MPR No. 11 tahun 1999).

Seperti halnya upaya pembinaan tari anak yang dilakukan di Sanggar Tari Putra Bimarespati. Upaya pembinaan tari yang dilakukan di sanggar Putra Bima Respati pada dasarnya sama dengan sanggar-sanggar tari yang lainnya. Hanya saja, pada sanggar Putra Bimarespati memiliki kedisiplinan yang lebih dalam pengajaran tari yang dilakukan. Kedisiplinan tersebut sangat jelas terlihat dalam proses latihan, ketepatan waktu latihan dan kedisiplinan dalam menari. Hal tersebut yang menjadikan para peserta sanggar mempunyai kualitas tubuh yang sangat bagus dalam menari.

Kedisiplinan dalam proses latihan terlihat seperti penerapan teknik tanjak yang harus benar-benar bagus dalam menari Remo. Tanjak yakni posisi kaki yang terbuka dengan menekuk kedua bagian lutut membentuk sudut 90 derajat. Selain posisi tanjak yang harus benar-benar dilakukan dengan tepat, teknik-teknik gerak lain seperti seblak sampur, kipat sampur, iket dan lain-lainnya juga harus dilakukan dengan serius, semangat dan tepat. Pelatih sangat ketat dalam memberlakukan kedisiplinan dalam teknik menari guna mendapatkan hasil yang maksimal.

Tidak ada pengelompokan yang khusus dalam pengajaran tari. Semua anak, besar, kecil, tua, muda dilatih secara bersama-sama. Jenis tari yang diajarkan di sanggar Putra Bimarespati adalah tari anak, tari kreasi, tari tradisional, dan lain sebagainya. Tetapi sanggar ini lebih mengutamakan mengajar jenis Tari Remo Gagrak Anyar di mana gerakan tari tersebut merupakan karangan dari bapak Saryono sendiri dan 
sudah dipatenkan untuk menyambut acara-acara resmi di Balai Kota Surabaya dan instansi pemerintahan di Surabaya.

Proses latihan tari di sanggar Putra Bimarespati dilaksanakan setiap hari Senin dan Selasa di Tambak Segaran. Waktu pelaksanaannya yaitu pukul 18.30 sampai selesai. Sedangkan setiap hari Rabu, Kamis, dan Jumat latihan dilaksanakan di Balai Pemuda pada waktu 18.30 sampai selesai. Untuk hari Sabtu, latihan dilaksanakan di Balai Pemuda pukul 18.30 sampai selesai.

\section{Prestasi Sanggar}

Prestasi berasal dari Bahasa Belanda yang artinya hasil dari usaha. Prestasi diperoleh dari usaha yang telah dikerjakan. Dari pengertian prestasi tersebut, maka pengertian prestasi diri adalah hasil atas usaha yang dilakukan seseorang. Prestasi dapat dicapai dengan mengandalkan kemampuan intelektual, emosional, dan spiritual, serta ketahanan diri dalam menghadapi situasi segala aspek kehidupan. Karakter orang yang berprestasi adalah mencintai pekerjaan, memiliki inisiatif, dan kreatif, pantang menyerah, serta menjalankan tugas dengan sungguh-sungguh. Karakter-karakter tersebut menunjukkan bahwa untuk meraih prestasi tertentu, dibutuhkan kerja keras (https://id.wikipedia.org/wiki/ Prestasi).

Seperti halnya prestasi yang telah diperoleh Sanggar Putra Bimarespati atas usaha kerasnya dalam latihan yang dilakukan rutin setiap minggunya. Adapun prestasi yang telah diperoleh di antaranya adalah Juara festival Tari Remo tingkat Surabaya. Selalu mendapatkan 5 besar terbaik kejuaraan piala bergilir Tari Kreasi tingkat Jawa Timur yang diadakan oleh Dinas Pariwisata Jawa Timur, dan masih banyak lagi.

Pementasan yang sering dilakukan oleh sanggar Putra Bimarespati meliputi tingkat Pro- vinsi, Nasional, dan Internasional. Adapun Tingkat Provinsi biasa dilakukan di Gedung Grahadi dalam acara Gunernur Jawa Timur. Tingkat Nasional yaitu dilakukan di Istana Negara. Sedangkan Tingkat Internasional pernah dilakukan di Korea, Prancis, Jepang, Austria, dan Brazil.

\section{KESIMPULAN DAN SARAN}

Berdasarkan pemaparan di atas, kesimpulan yang dapat diambil yaitu Latar belakang yang mendasari pembinaan tari anak di Sanggar Tari Putra Bimarespati adalah keinginan Saryono supaya generasi muda khususnya anak-anak di Surabaya tidak melupakan tari tradisional khas Surabaya salah satunya yakni Tari Remo. Selain itu, dengan berlatih menari, dapat membentuk rasa tanggung jawab pada diri sendiri dan juga orang lain. Melatih kedisiplinan dan juga memberikan pelajaran yang tidak pernah dipelajari pada dunia anak. Dengan belajar menari, anak akan mampu mengoordinasikan gerakan tubuhnya. Melatih motorik halus dan motorik kasar anak, sehingga anak mempunyai kepekaan emosi terhadap sesama. Memberikan kegiatan positif anak agar dapat mengurangi aktivitasnya yang mayoritas saat ini didominasi dengan bermain gadget.

Upaya Pembinaan Tari yang dilakukan di Sanggar Tari Putra Bimarespati dilaksanakan dengan tingkat kedisiplinan yang tinggi. Sehingga mampu mencetak para penari yang memiliki kualitas tubuh dan kualitas kepenarian yang bagus. Hasil yang diperoleh dari sanggar tersebut dapat digunakan sebagai bekal dalam mengembangkan diri dalam dunia kepenarian. Adapun prestasi yang telah diraih oleh sanggar tari Putra Bimarespati meliputi tingkat Provinsi, Nasional bahkan sampai Internasional. Adapun saran yang diberikan yakni terkait proses latihan 
yang diterapkan pada Sanggar Putra Bimarespati dapat digunakan sebagai acuan bagi sanggarsanggar lain untuk dapat mengembangkan kemampuan dalam teknik menari. Sehingga mampu bersaing baik tingkat Provinsi, Nasional bahkan sampai Internasional.

\section{DAFTAR RUJUKAN}

Anton, Howard. 2003. Aljabar Linear Elementer Edisi Kelima. Jakarta: Erlangga.
Ovi. 2012. Pemahaman Siswa SMP Terhadap Simbol Sama dengan dan Relasi Ekuivalensi dalam Menyelesaikan Persamaan Matematika Ditinjau dari Kemampuan Matematika. Tesis. Universitas Negeri Surabaya. (Tidak Dipublikasikan)

Skemp, Richard R. 1987. The Psychology of Learning Mathematics. New York: Penguin Books Ltd.

Sugiono. 2010. Memahami penelitian kualitatif. Bandung: CV Alfabeta. 


\section{PETUNJUK PENULISAN NASKAH}

1. Education and Human Development Journal berisi artikel tentang kajian teori dan hasil penelitian di bidang pendidikan.

2. Artikel dikirim belum pernah dimuat di media cetak lain, ditulis dalam bahasa Indonesia/Inggris dan diketik dengan program Microsoft Word dengan font 12, menggunakan huruf Times New Roman spasi 1,5, pada kertas A4 sepanjang 15-20 halaman, dikirim ke email: ehdj@unusa.ac.id

3. Identitas penulis artikel ditulis tanpa gelar akademik ditempatkan di bawah judul artikel disertai nama dan alamat institusi, alamat e-mail dan telepon/HP, untuk memudahkan komunikasi. Jika penulis terdiri dari empat orang atau lebih, yang dicantumkan di dalam judul adalah nama penulis utama, sedangkan nama penulis lainnya dicantumkan sebagai catatan kaki pada halaman pertama.

4. Artikel hasil penelitian memuat:

Judul

- Nama Penulis (tanpa gelar akademik)

- Abstrak (75-100 kata) dalam bahasa Indonesia dan Inggris dengan program Microsoft Word dengan font 12, menggunakan huruf Times New Roman spasi 1, pada kertas A4.

- Kata-kata kunci (maksimal 5 kata)

- Pendahuluan (tanpa subjudul) memuat latar belakang masalah, perumusan masalah, rangkuman kajian teoretis, dan tujuan penelitian

- Tinjauan pustaka (memuat sedikit teori yang mendasari tulisan)

- Metode

- Hasil dan pembahasan (dapat dibagi beberapa sub bagian)

- Simpulan dan saran

- Daftar pustaka (rujukan minimal 70\% terbitan 10 tahun terakhir dan hanya memuat sumber-sumber yang di rujuk saja)

5. Artikel kajian teoretis (non-penelitian) memuat:

- Judul

- Nama Penulis

- Abstrak (75-100 kata) dalam bahasa Indonesia dan Inggris

- Kata-kata kunci

- Pendahuluan (tanpa subjudul) memuat pengantar topik utama diakhiri dengan rumusan tentang hal-hal pokok yang akan dibahas.

- Subjudul

- Subjudul

- Subjudul

- Penutup

- Daftar pustaka

6. Sumber rujukan diharapkan dari sumber primer, seperti laporan penelitian (skripsi, tesis, disertasi) atau artikel hasil penelitian yang dimuat dalam jurnal berkala ilmiah, dan ditulis secara alfabetis.

7. Penulis diwajibkan menyumbang biaya penerbitan dengan besaran yang layak.

8. Daftar rujukan ditulis dengan tata cara seperti contoh berikut ini dan diurutkan secara alfabetis dan kronologis. Buku:

Anderson, D.W., Vault, V.D. \& Dickson, C.E. 1999. Problem and Prospects for the Decades Ahead: Competency Based Teacher Education. Berkeley: McCutchan Publishing Co.

Buku kumpulan artikel:

Saukah, A. \& Waseso, M.G. (Eds.).2002. Menulis artikel untuk jurnal ilmiah. (Edisi ke-4, cetakan ke-1). Malang: UM Press.

Artikel dalam buku kumpulan artikel:

Russel, T. 1998. An alternative Conception: Representing Representation. Dalam P.J. Black \& A. Lucas (Eds.), Children's Informal Ideas in Science (hlm.62-84). London: Routledge. 
Artikel dalam jurnal atau majalah:

Kansil, C. L. 2002. Orientasi Baru Penyelenggaraan Pendidikan Program Profesional dalam Memenuhi Kebutuhan Dunia Industri. Transpor, XX (4):57-61

Artikel dalam koran:

Pitunov, B.13 Desember, 2002. Sekolah Unggulan ataukah Sekolah Pengunggulan? Majapahit Pos, hlm. 4\&11.

Tulisan/berita dalam koran (tanpa nama pengarang):

Jawa Pos. 22 April, 1995. Wanita Kelas Bawah Lebih Mandiri, hlm.3.

Dokumen resmi:

Pusat Pembinaan dan Pengembangan Bahasa. 1978. Pedoman Penulisan Laporan Penelitian. Jakarta: Depdikbud. Undang-undang Republik Indonesia Nomor 20 Tahun 2003 tentang Sistem Pendidikan Nasional.2004. Malang: Angkasa.

Buku terjemahan:

Ary, D., Jacobs, L.C. \& Razavieh, A. 1976. Pengantar Penelitian Pendidikan. Terjemahan oleh Arief Furchan. 1982. Surabaya: Usaha Nasional.

Skripsi, Tesis, Disertasi, Laporan Penelitian:

Makmara. Thontjie.2009. Tuturan Persuasif Wiraniaga dalam Berbahasa Indonesia: Kajian Etnografi Komunikasi. Disertasi tidak diterbitkan. Malang: Pascasarjana Universitas Negeri Malang.

Makalah seminar, lokakarya, penataran:

Waseso, M.G. 2001. Isi dan Format Jurnal Ilmiah. Makalah disajikan dalam Seminar Lokakarya Penulisan Artikel dan Pengelolaan Jurnal Ilmiah, Universitas Lambungkurat, Banjarmasin, 9-11 Agustus.

Internet (Karya Individual):

Hitchcock, S., Carr, L. \& Hall, W. 1996. A Survey of STM Online Journals, 1990-1995: The Calm before the Storm, (Online), (http://journal.ecs.soton.ac.uk/survey/survey.html, diakses 12 Juni 1996).

Internet (artikel dalam jurnal online):

Widiati, Utami. 2008. Pembelajaran Membaca-Menulis melalui Buddy Journals untuk Meningkatkan Kemampuan Menulis Mahasiswa Jurusan Sastra Inggris. Jurnal Bahasa dan Seni. (Online), Tahun 36, Nomor 2, Agustus 2008 (http://sastra.um.ac.id, diakses 3 Februari 2010).

Internet (bahan diskusi):

Wilson, D. 20 November 1995. Summary of Citing Internet Sites. NETRAIN Discussion List, (Online), NETRAIN@ubvm.cc.buffalo.edu, diakses 22 November 1995).

Internet (e-mail pribadi):

Naga, D.S. (ikip-jkt@indo.net.id). 1 Oktober 1997. Artikel untuk JIP. E-mail kepada Ali Saukah (jippsi@mlg. ywcn.or.id).

9. Tata cara penyajian kutipan, rujukan, tabel, dan gambar mengikuti ketentuan dalam Pedoman Penulisan Karya Ilmiah Universitas Nahdlatul Ulama Surabaya, atau mencontoh langsung tata cara yang digunakan dalam artikel yang dimuat. Artikel berbahasa Indonesia menggunakan Pedoman Umum Ejaan Bahasa Indonesia yang disempurnakan (Depdikbud, 1987). Artikel berbahasa Inggris menggunakan ragam baku.

10. Semua naskah ditelaah secara anonim oleh mitra bestari (reviewers) yang ditunjuk oleh penyunting menurut bidang kepakarannya. Penulis artikel diberi kesempatan untuk melakukan perbaikan (revisi) naskah atas dasar rekomendasi atau saran dari mitra bestari atau penyunting. Kepastian pemuatan atau penolakan naskah akan diberitahukan secara tertulis. 